\title{
Romany Issue(s): The Images of Romanian Gypsies at Home and Abroad
}

\section{Anca Balcanu}

\section{(2) OpenEdition}

\section{Journals}

\section{Electronic version}

URL: http://journals.openedition.org/transtexts/251

DOI: 10.4000/transtexts.251

ISSN: 2105-2549

\section{Publisher}

Gregory B. Lee

\section{Printed version}

Date of publication: 1 December 2008

Number of pages: $64-82$

ISSN: 1771-2084

\section{Electronic reference}

Anca Balcanu, «Romany Issue(s): The Images of Romanian Gypsies at Home and Abroad », Transtext (e)s Transcultures 跨文本跨文化 [Online], 4 | 2008, Online since 15 October 2009, connection on 04 May 2019. URL : http://journals.openedition.org/transtexts/251 ; DOI : 10.4000/transtexts.251 


\title{
Romany Issue(s): The Images of Romanian Gypsies at Home and Abroad
}

\author{
ANCABALCANU
}

In a country where the Roma minority was enslaved during the $18^{\text {th }}$ and $19^{\text {th }}$ centuries, where during Ceausescu's era it did not have the right to exist and where calling someone a 'tzigan' is worse than insulting someone's mother, being a 'gypsy' cannot be easy. As a European country belonging to the European Union, Romania has to ensure equal chances for all its citizens, no matter what ethnic group they belong to. Reality is far from the written rules - some Romanians are more equal than others. Discrimination against the Roma minority goes beyond Romanian borders. Italy, France and other EU countries reject the difference of a people that does not have the same notions of social life. Discriminated against, but cherished; for 'gypsy' culture (music, rituals, ways of dressing) inspires and attracts people looking for a joy of life and a freedom of spirit it seems to provide. Between the rejection of individuals and the acceptance of their culture, at the crossroad of their history and the place they are allowed to have in History, the way the Roma are perceived today gives a powerful insight into the Romanian mentality. My paper will try to show the duplicity of this image as it is presented in the Romanian medias - newspapers, magazines, TV channels, web sites - there where the ordinary Romanian gives and receives the projection of him/herself as he/she conceives it.

ŢIGÁN, -Ă, țigani, -e, s.m., adj. I. S.m. 1. Persoană ce face parte dintr-o populaţie originară din India şi răspândită în mai toate țările Europei, trăind în unele părți încă în stare seminomadă. 2. Epitet dat unei persoane brunete. 3. Epitet dat unei persoane cu apucături rele. II. Adj. (Rar) Țigănesc. - Din sl. ciganinŭ. Cf. rus. țâgan.

[Gypsy, gypsies n., adj. I. n. 1. Person belonging to a population that has its origins in India and that has spread through almost every country of Europe, living in some parts in a semi-nomadic way. 2. Name given to a brunette person. 3. Name given to a person 
with bad habits. II. Adj. (rare) bohemian, in a bohemian manner - from the sl. ciganinŭ. Cf. rus. Tâanan.] ${ }^{1}$

ŢIGĂNÍ, țigănesc, vb. IV. Refl. A insista mult (şi în mod dizgraţios) pentru a obţine ceva; a cere ceva cu încăpățânare; $p$. ext. a se târgui, a se tocmi (mahalageşte). - Din țigan.

[To be, to act like a gypsy, v. Reflex., To insist a lot (and in a disgraceful manner) in order to obtain something; to ask something stubbornly; (extended sense) to bargain, to haggle (in a vulgar way) - from Gypsy] ${ }^{1}$

May 2007. The president of Romania, the new member state of the European Union, harassed by the questions of a reporter during his private activities, called her a "filthy gypsy". The next day, in front of the Parliament, members of the Romany minority protested against what civil society and the press considered as discrimination. The representative of the Romany minority in the Romanian Parliament stated in the following days that the President made this observation during a private conversation, in a private place, while he was nervous, and that it could not be described as a racial and discriminative statement against the gypsy minority.2 Most Romanians, he explained, use the term 'gypsy' (țigan) in a pejorative sense when they are angry. This negative and discriminatory meaning of the word is accepted by the Dictionary of the Romanian Language of the Romanian Academy.

November 2007. Ilie Măilăț, a Romanian immigrant, robbed an Italian woman, seriously injuring her and abandoning her in a deserted place where she died after three days of suffering. After discovering Măilăţ was a Romany ethnic, the Foreign Affairs Minister, Adrian Cioroianu (a historian and politician), said during an international press conference that "all gypsies who are breaking the law must be deported to the Sahara desert". During the press conference organised two days later in order to give an official apology, he still insisted on saying that "perhaps the deportation of the gypsies will not happen too soon". ${ }^{3}$ Neither Băsescu nor Cioroianu resigned. Moreover, the two episodes weren't isolated. Ironically, they happened during the "Decade of Roma Inclusion". ${ }^{4}$

\footnotetext{
${ }^{1}$ http:/ / dexonline.ro/search.php?cuv=TIGANÍ [12/04/2008].

2 CDI, "Reprezentantul rromilor în Parlament: Băsescu nu e rasist" [Romany representative in the Parliament: Băsescu is not a racist], Romania liberă, May 23d, 2007, www.romanialibera.ro [25/04/2007]. ${ }^{3}$ Costel Oprea, "Cioroianu recidivează" [Cioroianu reoffends], România liberă, 13 November 2007, www.romanialibera.ro [27/04/2008].

4 "The Decade of Roma Inclusion" is a human rights initiative to which governmental, corporate and non-profit organizations in the European Union, Romania and the United States are committed. The Decade is from 2005 to 2015.
} 
In what follows, I will analyse the manner in which the Romany minority is perceived in the Romanian press. As the subject is both broad and important, the analysis must be limited in time and space. I will therefore mainly deal with the written daily press. My theoretical framework will be supported by extracts from two weekly papers and a Fulbright conference that opened the Decade of Roma Inclusion in 2005. ${ }^{5}$ My research focuses on a time period of 13 months, from the beginning of April 2007 to the end of April 2008. I chose this particular period first of all because of the two episodes described above. Secondly, as 8 April is International Roma Day, it seemed logical to examine the manner in which the press covered the event for two consecutive years. Finally, I wanted to observe the way the Romanian Romany community was seen after the country joined the European Union.

I analysed the online archives of three Romanian daily newspapers: Evenimentul zilei [The Event of the Day], România liberă [Free Romania] and Adevărul [The Truth]. They are influential general newspapers with a national distribution. ${ }^{6}$ Apart from having a large audience among Romanians, they are all over 10 years old and are also seen as the 'traditional' newspapers.

The weekly opinion papers I studied were Dilema veche [The Old Dilemma] and Revista 22 [22 Magazine].7 I chose these as I wanted to see the manner in which the Roma minority is represented in the milieu of the elite, as the general public perceives these two magazines as being particularly sophisticated and elitist. Dilema veche is a weekly cultural magazine focusing on thematic editions, with the accent on essays, debate and literary journalism. ${ }^{8}$ The second publication, Revista 22 , is an independent weekly political analysis and cultural newspaper that is published by the first Romanian NGO, Grupul pentru dialog social [The Group for Social Dialogue]. It defines itself as "the best weekly Romanian newspaper of political culture" ${ }^{\prime}$ ?

The manner in which the information and the materials were researched and collected also requires some explanation. Even though it is politically correct in

\footnotetext{
${ }^{5}$ Fulbright Commission, Transcripts of the Promoting Human Rights for the Roma conference, 1 June 2005, http://bucharest.usembassy.gov/Fulbright/Roma_Conference_Strategies_en.html [17/05/2008] ${ }^{6}$ According to BRAT (Biroul Român de Audit al Tirajelor [The Romanian Audit Office of Newspapers Circulation]), between April 2007 and April 2008, the three mentioned papers had an average distribution of: 27,939 (out of 45,872 printed copies) Adevărul; 59,484 (out of 79,429 printed copies) Evenimentul zilei; 79,004 (out of 102,840 printed copies) România liberă, www.brat.ro [05/05/2008]. 7 According to BRAT, between April 2007 and April 2008, Dilema veche had an average distribution of 8,069 copies out of 13,286 printed copies, www.brat.ro [05/05/2008]. Revista 22 isn't registered in the BRAT and its distribution numbers aren't available.

${ }^{8}$ http:/ / ro.wikipedia.org/wiki/Dilema_veche [05/05/2008].

${ }^{9}$ http:/ / www.revista22.ro [05/05/2008].
} 
Romanian language to speak about a 'Rroma' or 'Roma' minority, most Romanians use the word 'tigan'.10 For this reason, I searched the newspaper archives for the words "rom", "rrom", "Romanes", "romi", "rromi", "țigan" and "țigani." Such a distinction is a very important parameter, as the analysis of the Agenția de monitorizare a presei [The Media Monitoring Agency] showed in its 2002 report. Mircea Toma, the director of the Agency, suggested that even though the centuriesold negative stereotypes about gypsies cannot be easily changed, something may be modified in the way in which the stereotypes are perceived. It is wrong to associate the word 'țigan' with every piece of news or information about the Romany minority, and journalists and the mass-media have to actively change this perception. ${ }^{11}$

Between 1 April 2007 and 30 April 2008, the newspapers subject to analysis published the following number of articles:

\section{Total articles}

$\begin{array}{cc}\text { Adevărul } & 132 \\ \text { Evenimentul zilei } & 186 \\ \text { România liberă } & 83\end{array}$

I separated the articles according to two criteria. The first was the type of article that the newspaper published. Was it an informative article, answering to the questions "who", "what", "when", "where", "why" and "how"? Or was it an opinion-based article, presenting not substantiated information, but the author's attitude towards the subject? ${ }^{12}$ Since the two weeklies are, by their nature, presenting not factual, but subjective articles, this part of my work concentrated upon the daily newspapers, with the following results:

\footnotetext{
${ }_{10}$ As found in the results of the opinion poll realised in December 2007 by the Gallup Romania at the request of the Romanian Agency of Governmental Politics on 1,177 people. $45 \%$ of the people interviewed stated that they are afraid foreigners are making a confusion between Romanians and Rroma - Popescu Andrei Luca, "Românii se tem să nu fie confundați cu rromii" [Romanians are afraid to be mistake with Romany], România liberă, 10 December 2007,

http:/ / www.romanialibera.ro/a113228/romanii-se-tem-sa-nu-fie-confundati-cu-rromii.html [25/04/2008]; "Studiu Gallup: majoritatea românilor vor ca romii să fie numiți țigani" [Gallup Study: the majority of Romanians wants the Romany to be called gypsies], Adevărul, nr. 5415,

http:/ / www.adevarul.ro/articole/studiu-gallup-majoritatea-romanilor-vor-ca-romii-sa-fie-numititigani/334441 [20/05/2008];

11 Presa de la "Tigani" la "Romi" [The press from "Gypsies" to "Romany"], Aşezământul Cultural Academia Cațavencu, March 2002, p. 6.

12 The methodology I used follows that used by Presa de la "Tigani" la "Romi" [The press from "Gypsies" to "Romany"], Aşezământul Cultural Academia Cațavencu, March 2002, p. 8.
} 


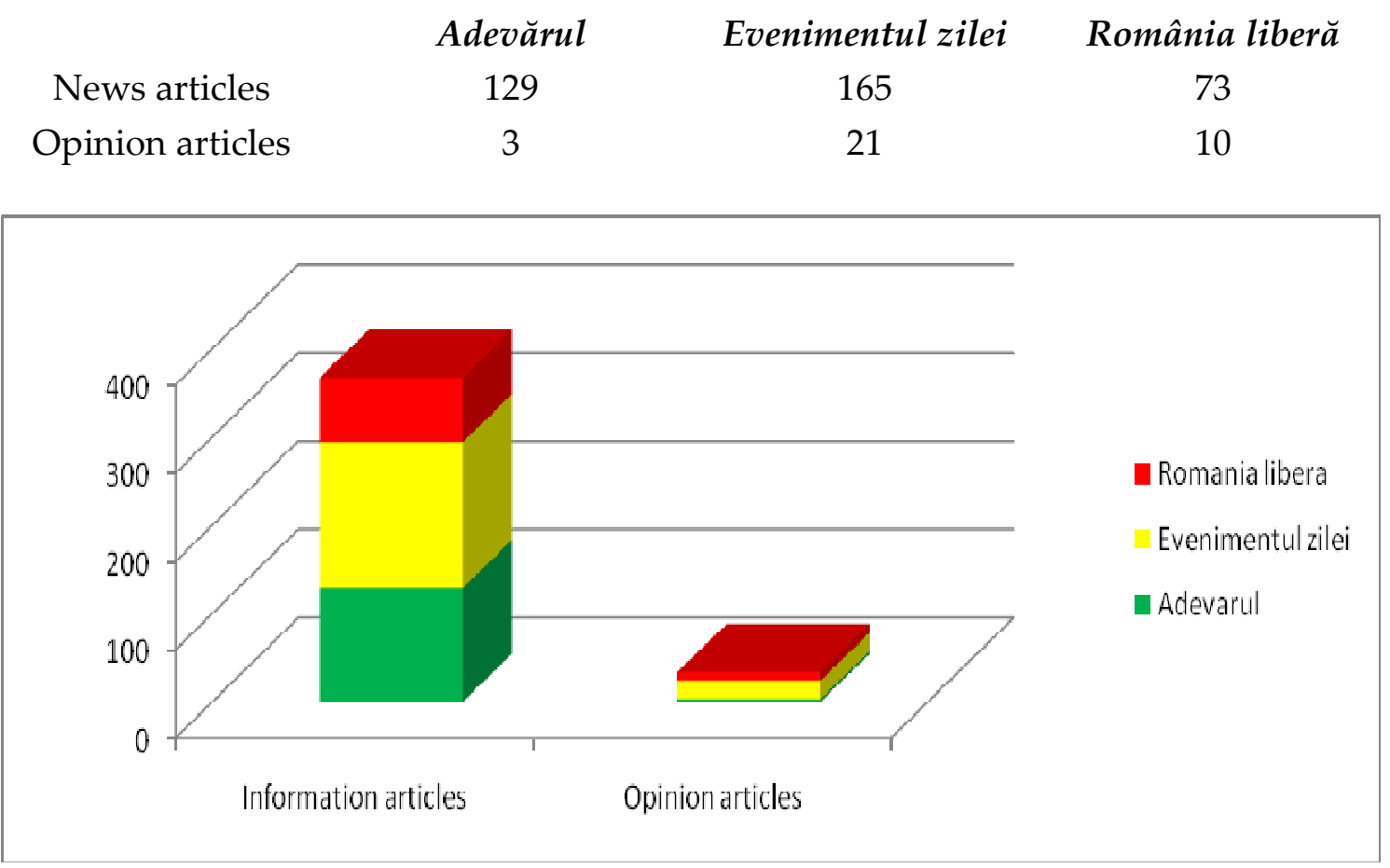

Figure 1

Dilema veche had 29 articles and Revista 22 had 9 articles dealing with Romany issues. Each of them had one special edition on the Romany minority during the period under investigation, to be more precise, after the November 2007 assassination of the Italian woman by Ilie Măilăț. While Dilema veche concentrated on political correctness and the integration of the Romany minority into Romanian society, Revista 22 analysed the way in which the Romanian Romany minority is perceived in the European Union, where large numbers of Romanian Romanies emigrated after the events of 1989.

My attention was first caught by the debate over how the minority should be called: 'țigan' [gypsy] or 'rom' [Romany]. It is a debate that appears every now and then in each of the newspapers cited above. Even the Media Monitoring Agency tried to show in its 2002 report how the shift from one word to another in the Romanian press operates, for “Utilizarea denumirii 'țigan' induce in multe cazuri o tendință negativă a jurnalistului în relatarea evenimentelor" [The use of the term 'gypsy' indicates in many cases a negative tendency of the journalist when relating the event]. ${ }^{13}$

My research showed the following results when searching for the words in the newspaper archives:

13 Presa de la "T,igani" la "Romi", p. 15. 


$\begin{array}{cccccc} & \text { Adevărul } & \text { Evenimentul zilei } & \text { România liberă } & \text { Dilema veche } & \text { Revista 22 } \\ \text { Rom } & 132 & 139 & 58 & 19 & 9 \\ \text { Tigan } & 0 & 47 & 25 & 10 & 0\end{array}$

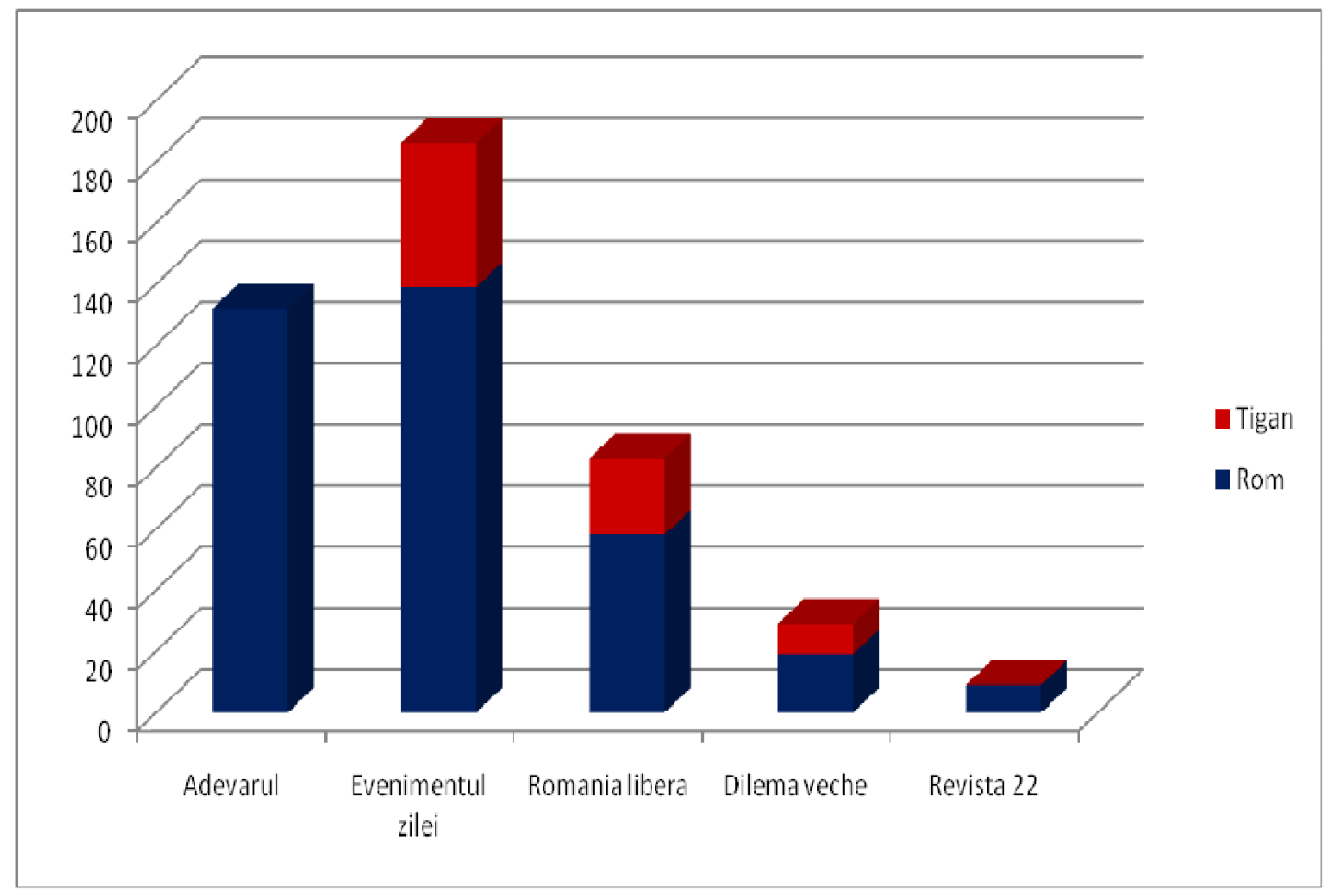

Figure 2

The problem of how the minority should be called -'tigan' or 'rom' - is a very important, as well as old issue. Although it is politically correct and humane to call someone a Romany rather than a gypsy, attitudes haven't changed very much, and you can still hear not only ordinary people using the word 'tigan' with a negative or pejorative meaning, but also Government representatives, including the President of Romania. It is a debate that inflames Romanians - the reactions to each article dealing with the subject are many and passionate. Intellectuals, historians and journalists all debate the subject. Before moving on to the presentation of the articles found during my research, I would like to analyse the main position of the Romanian intelligentsia in this large debate which has been a bone of contention for decades.

How should the Romany minority be called? And why so? The debate that Dilema 
veche opened in 2006 with two special issues of the magazine, started from an observation: in Romania one talks about gypsies either in a very placatory manner, using the word 'Romany' and explaining the discriminations the minority suffers; or harshly, with a lot of resentment, by discussing "gypsies" as a social problem. ${ }^{14}$ So what is the most important in a person, their colour (or race) or their nature (or character)? What is the most annoying and disturbing for the Romanian majority; the colour of the minority, or its people's nature? ${ }^{15}$ To the question there were multiple answers. I shall try and review their main points.

There are those, like Voicu, who consider that by calling a 'gypsy' by the politically correct term 'Romany', one discriminates even more against them by applying a word which is strange to the traditional language. The majority therefore transform them into some kind of extraterrestrial creatures that will be easier to remove from the body of the society. ${ }^{16}$ The risk is bigger, Voicu continues, as we have the tendency to remove the identity from a population that, during the communist period, was forbidden to exist. Defining the 'gypsies' as 'Romany' therefore discriminates against them. Giving media coverage to the Romany issue creates the real problem: Romanians will consider them as strange entities they should avoid by socially marginalizing them.

However, in the Romanian language, 'țigan' means more than a "person belonging to a population that has its origins in India and that has spread through almost every country of Europe, living in some parts in a semi-nomadic way". Starting from the lexicological meanings of the word 'țigan', Marina Dumitrescu shows that in Balkan regions, the polysemy of the word 'țigan' is more marked than in French or English. 'Tigănie', even if at the root of the word originally meant a gypsy community or place where this community lives, in Romanian it developed a connotation of which people are acutely aware. The word is associated with filth, disorder, dishonesty, noise, abhorrent smells, and a half-animal, uncivilised world. ${ }^{17}$

Domuţa considers that aside from the linguistic and sociological questions, 'gypsies' do not need to integrate into the society proper, for they are already part of the society. 18 They have belonged to the Romanian nation for centuries, and as

14 “Cine e țigan?" [Who is gypsy?], Dilema veche, III year, no. 127, 30 June 2006, http:/ / www.dilemaveche.ro/index.php?cmd=numar\&nr=127 [14/09/2007].

${ }^{15}$ Giurgeanu Stela, "Argument" [Argument], Dilema veche, III year, no. 127, 30 June 2006, http:/ / www.dilemaveche.ro/index.php?nr=127\&cmcd=articol\&id=1638 [14/09/2007].

16 Voicu Bogdan, "Roma Issues", Dilema veche, III year, no. 127, 30 June 2006,

http:/ / www.dilemaveche.ro/index.php?nr=127\&cmd=articol\&id=1643 [14/09/2007].

17 Dumitrescu Marina, “Delimitări : țigănie fără țigani” [Demarcations: gipsydom without gypsies],

Dilema veche, III year, no. 127, 30 June 2006,

http:/ / www.dilemaveche.ro/index.php?nr=127\&cmd=articol\&id=1643 [14/09/2007].

18 Domuța Dorin C., “Despre integrarea țiganilor" [About the integration of gypsies], Dilema veche, III 
Romanian citizens they enjoy the same rights and also the same responsibilities. Maybe the real problem is that the mentality of some of the Romany people must change - after all - we are talking about members of the minority that refuse to respect common-sense rules and Romanian laws by claiming that they belong to another type of culture. Domuţa suggests the eradication of all customs that lead to a violation of the law (like the tradition of organising the marriage of children) or those that put in danger the safety, good health and wellbeing of entire communities (and here education plays the most important role).

However, confusion appears even among members of the minority. As Mălina Voicu shows, changing the name of a minority does not lead to a change in its identity. ${ }^{19}$ The Romany people are an ethnic group that for centuries had an inferior status, and of course, the idea of changing their name is part of a larger programme seeking to redefine their ethnic identity and integrate them into society not by assimilation, but by the acceptance of difference. Apart from the name, the most important element is the general attitude and the behaviour of the majority towards the minority. From another perspective, the gypsies are a very heterogeneous group. Romany people are not simply people with colourful dresses and scarves or with a traditional way of life, known for playing traditional music. 'Gypsy' can refer to people living on the periphery of cities, poor and miserable, as well as to people living in palaces. Between all these groups are important cultural, educational and social differences. Many people of the Romany community do not accept the term Romany and confusion arises maybe from the fact that the label 'rom' was artificially invented but not assumed by the large majority.

But contrary to the conclusion of Voicu, that every person should have the right to call him- or herself as he or she desires, Margareta Matache, the executive director of the NGO Romani CRISS, is absolutely convinced that the 'Romany' appellation is the correct one, for 'țigan', 'gypsy' or 'zigeuner' have all a negative connotation. ${ }^{20}$

The opinion of Matache (the only Romany that gave her opinion on the matter in the special issue Dilema veche) is advocated by a series of other Romany intellectuals in the second part of the debate. ${ }^{21}$ Delia Grigore states that the present identity of

year, no. 127, 30 June 2006, http:/ / www.dilemaveche.ro/index.php?nr=127\&cmd=articol\&id=1642 [14/09/2007].

${ }^{19}$ Voicu Mălina, “Tigani sau romi?” [Gypsy or Romany?], Dilema veche, III year, no. 127, 30 June 2006, http:/ / www.dilemaveche.ro/index.php?nr=127\&cmd=articol\&id=1672 [14/09/2007].

${ }^{20}$ Giurgeanu Stela, “O etapă esențială: educația interculturală” [An essential phase: the intercultural education], Dilema veche, III year, no. 127, 30 June 2006,

http:/ / www.dilemaveche.ro/index.php?nr=127\&cmd=articol\&id=1742 [14/09/2007].

21 “Noi suntem romi" [We are Romany], Dilema veche, III year, no. 141, 6 October 2006, 
Romany people in Romania is based on a history of social exclusion and institutional racism, rooted in negatively stereotyped thinking. "Ţigan" is a false name, for in the Romany language this word does not exist: it is a word of Greek origin referring, in the official religious orthodox system, to the "impure", "pagan", "untouchable" ones. ${ }^{22}$ In the fourteenth century, when the word 'atigan' was mentioned for the first time in religious documents, the term was a reference to the social condition of gypsy slaves, and had nothing to do with their ethnic group. ${ }^{23}$ It should be mentioned that the slavery of the gypsies was a scourge of the Romanian nation, for even after its abolition, the Romany minority has been considered to be a parasitic subculture, a socially excluded group formed of entities that have not been allowed to enjoy their fundamental human rights. ${ }^{24}$ Grigore draws attention to a very important aspect of the development this collective image of the majority towards the gypsy minority has taken: self-stigmatization. "Modelul unic de referinţă se circumscrie autarhic şi inflexibil valorilor majorităţii." [The unique reference model refers invariably and inflexibly to the values of the majority]. ${ }^{25}$ This is how gypsies become the prisoners of a deforming society. By adopting only on the surface the way of life of the majority, they return an image of an imperfect society, and as a result, the majority starts doubting its own identity and rejects the stranger that tells them the truth. ${ }^{26}$

This 'deformed' society is that which fails to teach the young generations (for the subjects mentioned below are not even referred to in history course books) about the five centuries of slavery the gypsy minority endured: the Holocaust, during which gypsies were as much victims as Jews; about the Second World War, when Romanian gypsies were deported to Transnistria; or about the Romanian Orthodox Church which openly associated its name with (and also encouraged) the Romanian extreme right movement between the two World Wars. ${ }^{27}$

\footnotetext{
http:/ / www.dilemaveche.ro/index.php?cmd=numar\&nr=141 [02/10/2008].

22 "athinganos", "athinganoy"

${ }^{23}$ In Moldavia (1428) and in Valahia (1385) the first mentions of "atigani" are in documents of inventory of goods of some monasteries - http:/ / www.rroma.eu/sclavia-rromilor.aspx [13/04/2008].

24 The abolition of slavery in Romanian countries took place between $1843-1855$. First the slaves of princes were freed, then the monasteries' slaves and in the end the nobility's slaves. -

http:/ / www.rroma.eu/sclavia-rromilor.aspx [13/04/2008]; also "Pe urmele robilor lui Golescu" [Following the slaves of Golescu], Evenimentul zilei, nr. 5052, 19 January 2008, http:/ / www.evz.ro/articole/ detalii-articol/473863/Pe-urmele-robilor-lui-Golescu/ [19/03/2008]. ${ }^{25}$ Grigore Delia, “Ecourile de azi ale robiei” [Today's echoes of slavery], Dilema veche, III year, nr. 141, 6 October 2006, http://www.dilemaveche.ro/index.php?nr=141\&cmd=articol\&id=3993 [02/10/2006]. ${ }^{26}$ Rădulescu Bogdan, “Tiganii sunt fericiți când sunt altceva decât ... țigani” [Gypsies are happy when they are anything else than ... gypsies], România liberă, 10 November 2007,

http://www.romanialibera.ro/a110944/tiganii-sunt-fericiti-cand-sunt-altceva-decat-tigani.html [25/04/2008].

${ }^{27}$ Manole Petre Florin, “Omisiuni” [Omissions], Dilema veche, III year, nr. 141, 6 October 2006,
} 
But all the arguments for and against calling Romanian gypsies 'tigani' or 'rom' are intellectual ones. In the everyday Romanian media, things don't seem to have changed very much. The debate about how the gypsies should be referred to surfaces only after episodes like those cited at the beginning of my paper, and the arguments presented are few: the word 'țigan' has a negative connotation, Romanians are afraid that there will be a confusion between the 'Romany' and 'Romanians' (but nobody says that the Romany are also Romanian citizens) and that in Romani (the gypsy language) the term 'țigan' does not exist. ${ }^{28}$

The newspaper Adevărul launched a campaign, "Țiganii, o problemă europeană" [The gypsies, a European problem] that, as stated by the chief editor, posed a clear question: Who really cares about the Romany community? Is there a real desire on the part of the European community to integrate these people to normality since everywhere, in Romania or the European Union, they are treated as guilty from the outset. ${ }^{29}$ The Romany is a minority the European Union does not want among its citizens. The statistics show that in the EU there are approximately 12 million Romany, but few of them are European citizens. The old continent chose to either turn its back to this minority, by chasing it away or persecuting it, or to integrate it by force. One may even speak of a careless and discriminatory attitude of the European Union towards the Romany communities. The European Union is even accused of sending significant sums of money from Western European countries to Central and Eastern Europe through different "multicultural" programmes with the declared objectives of "cultivating tolerance" or "multi-ethnic co-habitation" although their only purpose being to stop the Romany from invading the West. ${ }^{30}$ They are the failed examination for the EU, and Leonard Orban, the Romanian Commissioner, states that the global problem has been transferred to a local level. ${ }^{31}$

The Romany people are considered by one editor to be the $28^{\text {th }}$ nation of the

\footnotetext{
http:/ / www.dilemaveche.ro/index.php?nr=141\&cmd=articol\&id=4022 [02/10/2006].

${ }^{28}$ Mihalcea Eugenia, "”Rom sau tigan” [Romany or Gypsy], Evenimentul zilei, nr. 5051, 16 January 2008, http:/ / www.evz.ro/article.php?artid=337529 [16/01/2008]; Gavreliuc Alin, "Despre "țigani" şi "țigănitate"" [About "gypsies" and "gipsydom"], Evenimentul zilei, nr. 4833, 14 June 2007, http:/ / www.evz.ro/index.php?zone=articole\&task=detalii-articol\&item $=447179 \& p a g e=A L I N-$ GAVRELIUC-Despre-quottiganiquot-si-quottiganitatequot\&current_date=2007-06-14 [05/05/2008]. ${ }^{29}$ Ciocăzanu Laurențiu, “Nu trageți în rromi!” [Do not shoot the Romany!], Adevărul, nr. 5389, 7 November 2007, http://www.adevarul.ro/articole/nu-trageti-in-rromi/331324 [07/11/2007]. 30 Şuteu Adina, "Rromii o minoritate pe care Europa nu o vrea" [Romany, a minority Europe doesn't want], Adevărul, nr. 5389, 7 November 2007, http:/ / www.adevarul.ro/articole/de-ce-nu-iubimtiganii/331280 [07/11/2007].

${ }^{31}$ Popescu Andrei Luca, “Romii, o restanță pentru Europa” [Romany, a failed exam for Europe], România liberă, 24 March 2008, http:// www.romanialibera.ro/a120765/romii-o-restanta-pentrueuropa.html [27/04/2008].
} 
European Union, for they are a nomadic people in a Union with no borders between its member states and where transparency and permeability rule. ${ }^{32}$ Another opinion that expresses in a metaphorical manner the way citizens of the European Union make the distinction between the 'Romany' and the 'gypsy' is that of Cristea Radu Călin: “Etnicul rrom, privit de occidentalul amator de exotisme contemplate de pe şezlong, e cu siguranţă altceva decât ţiganul în carne şi oase carei fură occidentalului şezlongul de sub el şi îi mai răpeşte şi menţionatele reverii." [The ethnic Romany, as seen by the Westerner who appreciates the 'exotic' from his or her lounge, is for sure totally different from the gypsy in flesh and bones that steals from the lounge they are sitting in and the above mentioned dreams together with it]. ${ }^{33}$

However, apart from Western spectators appreciating the exotic culture of Romanian Romany from afar, there are some western initiatives that receive good media coverage and which change the life of the minority. Leslie Hawke, for example, created the association "Ovidiu Rom", which promotes the education of children from the Romany minority, organises charity events and works in an active way to improve the future life of the minority. ${ }^{34}$ Leslie Hawke, as director of the association, brought back to school over 500 children. In fact, as many as 1,700 children, many of whom didn't know the names of colours or numbers, could close their educational gap and more than 300 families were helped to keep their children in school. But, most of all, Hawke initiated a movement that redefines the integration of the Romany community as a whole: keeping children in school doesn't only mean keeping them in a building for seven hours a day, but also means teaching them to deal with daily hygiene, keeping them properly fed and having social workers explain to their families the importance of a good education. For some of them, going to school, no matter at what their age, also helps them get registered in official documents, for a large part of the Romany minority does not exist in the eyes of the state as its members aren't registered in any official papers.

In fact, 152 years after their liberation from slavery, the Romany minority is still confronted with the same problems: poverty, inferior status among the other Romanians and lack of education. Could the solution be, as Iosif Klein Medeşan proposes, a well-founded, coherent policy which implements educational and social integration programmes? ${ }^{35}$ One of the first impressions when reading all the

\footnotetext{
32 Stanca Dan, "A 28-a națiune a Europei" [The 28th nation of Europe], România liberă, 22 August 2007, http:/ / www.romanialibera.ro/a104176/a-28-a-natiune-a-europei.html [01/05/2008].

33 Călin Cristea Radu, "Între rrom şi țigan” [In between Romany and Gypsy], Adevărul, nr. 5398, 7

November 2007, http://www.adevarul.ro/articole/intre-rrom-si-tigan/331220 [07/11/2007].

${ }^{34}$ România liberă (4); Evenimentul zilei (2).

${ }^{35}$ Medeşan Iosif Klein, "Servitute şi dreptate" [Slavery and justice], România liberă, 21 March 2008,
} 
research material is that there are two types of newspaper article: the politically correct articles, the ones that use unbiased language, are based on facts or offer, in a unemotional manner, the opinion of the authors; and the negatively-orientated articles, suggesting that the gypsy minority is responsible for the negative image Romania has among other countries, or that it is a negative element of Romanian society.

I tried to figure out a classification for the articles published. The classification is based on what was considered newsworthy. For example, the fact that some Romanian gypsies are expelled from other EU countries will attract more readers to an article than the latest social integration programme developed by one or another NGO. The articles are mainly based on three general themes: the Romany in Romania, the Romany in foreign countries and Romany culture. Each main theme is divided into sub-themes. For each theme I will mention the number of articles that each journal published in the period under investigation.

\section{The Romany Community in Romania}

\subsection{Social Problems Relating to the Romany Community}

Journalists speak mainly about the unacceptable living conditions of the Romany minority in Romania, ${ }^{36}$ their poverty, ${ }^{37}$ their recognition as a minority group in Romania $^{38}$ and their migration inside the borders of Romania, ${ }^{39}$ as well as the education of Romany children ${ }^{40}$ or even cases of abandoned Romany children. ${ }^{41}$

\subsection{Romany Crimes}

This is one of the most prevalent stereotypes in Romania. In fact, the March 2002 report, "the Media Monitoing Agency - presa de la "ţigani" la romi", found more than 43 articles $-50 \%$ of the total registered - about negative events in which the actors were the Romany: "am remarcat faptul că ziarele care prezintă evenimente conflictuale au tendinţă pentru prezentarea acțiunilor negative săvârşite de etnicii romi" [We noticed that the newspapers that present events relating to conflict had the tendency to present the negative actions of the Romany ethnics $]^{42}$. The criminal

http:/ / www.romanialibera.ro/a120601/servitute-si-dreptate.html [28/04/2008].

${ }^{36}$ Evenimentul zilei (7), România liberă (5).

${ }^{37}$ Adevărul (1), Evenimentul zilei (4), România liberă (2).

${ }^{38}$ Evenimentul zilei (3).

${ }^{39}$ Evenimentul zilei (1).

${ }^{40}$ Adevărul (2), Evenimentul zilei (2).

41 Adevărul (1).

42 Presa de la "Tigani" la "Romi" [The press from "Gypsies" to "Romas"], Aşezământul Cultural Academia Cațavencu, March 2002, p. 12. 
Romany has an important presence in Romanian newspapers. The Romany is seen as a violent community that puts in danger the calm way of life of the majority ${ }^{43}$ and is often in possession of guns. ${ }^{44}$ In order to deal with that, the solutions found vary from sending Romany ethnics undercover in dangerous places (to spy on their co-ethnics and report future-planned crimes to the police); ${ }^{45}$ to resorting to the help of the "bulibaşă", the traditional Romany leader who imposes himself in front of the community (a similar solution was tried in the 80s and 90s in France in relation to African immigrant communities with "le Grand frère" from the suburbs). ${ }^{46}$ If the solutions mentioned above do not work, there is always a third one: meetings between Police delegates and Romany representatives. ${ }^{47}$

An interesting episode took place during the events of November 2007, following the crime committed in Italy by a Romany Romanian mentioned above. After the discriminatory declarations made by the Romanian Foreign Affairs Minister, Cioroianu, during his visit in Italy, he was forgiven in front of the media by the well-known Romany Romanian outlaw Costică Argint - a political refugee in Italy.48

The Romany community is also involved in organised crime, including bank frauds, ${ }^{49}$ prostitution, human traffic and beggars' networks, ${ }^{50}$ but also in what has been known as the "afacerea baştanilor" [the affair of the bosses] - a real-estate fraud in which a Romany organisation threatened the inhabitants of Timişoara so much that its members succeeded in buying an entire district of the city. ${ }^{51}$ This category also includes crimes of which Romany ethnics have been victim. Here, we can mention both the misappropriation of funds intended for the Romanies ${ }^{52}$ and the use of the Romany communities as an electoral weapon. ${ }^{53}$

\subsection{Discrimination}

In Romania, discriminating against the Romany minority seems to be rooted in attitudes, so that starting with the President, and continuing through the Prime Minister, school teachers, reporters and journalists, all the way down to the ordinary Romanian, everyone speaks about filthy gypsies, gypsy thieves or the now proverbial gypsy laziness.

\footnotetext{
${ }^{43}$ Adevărul (4), Evenimentul zilei (8), România liberă (4).

${ }^{44}$ Adevărul (2), Evenimentul zilei (3), România liberă (1).

${ }^{45}$ Adevărul (1).

${ }^{46}$ Adevărul (1).

47 Adevărul (1).

${ }^{48}$ Evenimentul zilei (2), România liberă (1).

${ }^{49}$ Evenimentul zilei (2), România liberă (1).

${ }^{50}$ Adevărul (2), Evenimentul zilei (3), România liberă (1).

${ }^{51}$ Evenimentul zilei (8), România liberă (3).

52 Adevărul (1).

53 Adevărul (1), România liberă (1).
} 
As mentioned at this beginning of the paper, the President of the country, feeling harassed by a reporter who kept asking him questions while he tired to embark on a private activity (shopping with his wife), took her mobile phone and said to his wife, when left alone with her, that the reporter was a "filthy gypsy". Unfortunately for him, the phone registered the entire conversation. The echoes were numerous, the President apologised through his spokesperson, the Romany protested in front of the Parliament using soap, detergents and wearing T-shirts bearing the logo "Filthy gypsy". The Romany representative in Parliament concluded that in his opinion, the comment made by the President was not discriminatory since everybody in the country uses this expression and we are all allowed a degree of latitude in expressing ourselves when nervous. ${ }^{54}$

In July 2007, it was the Prime Minister who was accused of making discriminatory comments against the Romany community. He declared during his weekly meeting with the press that it didn't seem right to him that honest Romanians who go to work in Italy should suffer because of the criminal acts committed in the Peninsula by Romanies. For associating criminality with the Romany ethnics, the Romani Criss association took legal action against the Prime Minister. The National Council against Discrimination found the Prime Minister not guilty. ${ }^{55}$

After the events outlined above, the decision of a school to make separate classes for Romany pupils passed almost unnoticed. ${ }^{56}$ Discrimination in schools against Romany children is a phenomenon that appears periodically in the Romanian press. Some teachers call their Romany pupils either "filthy gypsies" 57 - following the Presidential declarations - or they imitate the sound of the crows when addressing them (as if you want to really offend a Romany, you do not call him "țigan", but "crow"). 58

Against all the discrimination, the Romany complained to the Government ${ }^{59}$ and sent open letters to the President. ${ }^{60}$ No result was published in the press. In November 2007, Adrian Cioroianu, Romania's Foreign Affairs Minister, followed the non-discriminatory statement issued by the Prime Minister by declaring that all gypsies should be deported to the Sahara desert, for they are criminals and

\footnotetext{
${ }^{54}$ Adevărul (6), Evenimentul zilei (3), România liberă (7).

${ }^{55}$ Evenimentul zilei (3), România liberă (1).

${ }^{56}$ Evenimentul zilei (1).

${ }^{57}$ Evenimentul zilei (1).

${ }^{58}$ Evenimentul zilei (1).

${ }^{59}$ Evenimentul zilei (1).

${ }^{60}$ Adevărul (1).
} 
outlaws. ${ }^{61}$ Save the Children, the European Court of Human Rights and the European Parliament all condemn Romania for discrimination against the Romany minority after episodes like those mentioned above. ${ }^{62}$

\subsection{Integration of Romany Minority}

Little by little, some things are done for the integration of the Romany community. Seminars are organised (even too many in the opinion of some journalists ${ }^{63}$ ), special places are reserved for Romany students in universities ${ }^{64}$ and job opportunities are created for Romanies. ${ }^{65}$ The President made the integration of the Romany community one of his priorities, and he considers them to be Romanians with the same rights and the same obligations as the other Romanians. ${ }^{66}$ The projects for integrating the Roma minority are carried out both at local ${ }^{67}$ and national ${ }^{68}$ level, either by the authorities or NGO's ${ }^{69}$ Romany ethnics can now be found in the police force, the media and schools, and their leaders are participating in making decisions concerning the minority ${ }^{70}$.

\subsection{Traditions}

Romany traditions are of two kinds: those accepted by the majority, like their crafts, their folklore, their music, dances and their organisation; ${ }^{71}$ and those which are in total contradiction with the most elementary human rights. Among the latter, the most mediatised is the marriage of Romany children. Two important events took place during the period investigated: one of them was the marriage of a five-yearold girl with a sixteen-year-old boy; ${ }^{72}$ the other was a twelve-year-old boy's rebellion against this tradition by refusing to get married to the girl his parents chose for him - the result was a general battle between the two clans and the image of a generation gap. ${ }^{73}$

\section{The Romany Community in the EU}

\footnotetext{
${ }^{61}$ Adevărul (4), Evenimentul zilei (4), România liberă (1), Dilema veche (2).

${ }^{62}$ Adevărul (1), Evenimentul zilei (2), România liberă (4).

${ }^{63}$ Evenimentul zilei (1), România liberă (1), Revista 22 (1).

${ }^{64}$ Evenimentul zilei (1), România liberă (1).

${ }^{65}$ Adevărul (1), Evenimentul zilei (1), România liberă (1).

${ }^{66}$ Adevărul (2).

${ }^{67}$ Adevărul (1), Evenimentul zilei (1).

${ }^{68}$ Adevărul (1).

${ }^{69}$ Evenimentul zilei (3), Dilema veche (1)

${ }^{70}$ Adevărul (2), Evenimentul zilei (2).

${ }^{71}$ Adevărul (2), Evenimentul zilei (5).

${ }^{72}$ Evenimentul zilei (2).

${ }^{73}$ Adevărul (1), Evenimentul zilei (5).
} 
Between the countries of the European Union, the ways in which the Roma issues are treated are very different. There is no common European policy concerning the Romany minority. The EU puts aside funds and finances programmes for Romany integration, but leaves finding solutions to the states themselves. ${ }^{74}$ Two neighbours, France and Italy, have radically opposing approaches to the Roma issue. I limited my research to these two countries, and I will present the main subjects the Romanian press published, although there are also articles about the Romanian Romany beggars that invaded Greece, Finland, Spain, UK and Ireland. ${ }^{75}$

\subsection{The Măilăț Case and the Italian Crisis}

Although the European Union has allocated funds for the integration of the Roma minorities, not all the countries that have Romany ethnics on their territory asked for that money. Such is the case with Italy, a country which saw its own transformation from a net exporter of people to a net importer. Since 1996, more and more Romanians have decided to go work, live and sometimes settle in Italy. Romanians are the largest minority community in Italy (officially more that 600,000 Romanians live there, and unofficially almost 2,000,000) and some of them are Romany ethnics.

Before the Măilăț episode occurred, there had already been xenophobic and discriminatory acts committed against Romanian Romanies, for example, a Romanian Roma camp was intentionally set on fire in Ascoli and the Italian police forces entered into conflicts with Romany camps in Milano, Rome, and Napoli. ${ }^{76}$ But the crime committed on 30 October started an anti-Romanian Romany campaign in the Italian press, allowed the Italian Right to gain ground in the elections and almost led to a diplomatic conflict between the two countries. In Romania, the effects were comparable - no other such event had succeeded in bringing extreme-right marches to the streets (except a gay parade), or inflaming the pages of newspapers and stigmatising in such a way the Romany minority. ${ }^{77}$ The problems are still not solved: Italy tried twice to pass a law against the free movement of Eastern European citizens, although it did not succeed, for it contradicts one of the fundamental rights of European citizens - freedom of movement. Once a week, the press in both countries publish articles about the crimes committed by Romany ethnics on Italian territory. ${ }^{78}$

\footnotetext{
74 Adevărul (6), Evenimentul zilei (2), România liberă (2).

${ }^{75}$ Adevărul (9), Evenimentul zilei (12), România liberă (4).

${ }^{76}$ Adevărul (14), Evenimentul zilei (8), România liberă (3).

77 Adevărul (43), Evenimentul zilei (56), România liberă (19), Dilema veche (4), Revista 22 (8).

78 While the Cultures in Transit Conference was taking place, Italy started to fingerprint all the Romany
} 


\subsection{The French Integration Programme}

At the opposite end of the spectrum, France seems to have found a way in which the Romany issue could be solved. The scheme is based on more that 15 years of collaboration between regions in France and Romania (mainly in agricultural regions, French farmers showing to their Romanian couterparts what modern agriculture means and how EU policy can successfully be put in practice). The French government developed an economic integration programme for Romanian Romanies who were forced to leave their places of origin due to poverty. To be more precise, the French government gives the equivalent amount of animals (sheep, goats or pigs) to 1,000 euros for each Romany adult and 500 euros for each Romany child that agrees to leave French territory and return home to start an agricultural business.

Of course, not all the cases are success stories: there are Romanies who take the subventions from the French government, sell the animals and after half a year return to France in order to be sent home again. But the programme is a long-term operation, and nobody can say for now if it is a failure or a success. ${ }^{79}$

\subsection{Romany Culture}

"United in diversity" - such was the motto of the European Union. But is it a reality when it comes to the Romany minority? Are EU countries and citizens united when it comes to a totally different culture than the one they are used to? Could culture create bridges and destroy the walls of rejection, intolerance and racism? Apparently it can, if one judges by the numerous Romany cultural projects financed by the EU.

\subsection{International Roma Day}

In 1971, at the first World Romany Congress, 8 April was declared the International Roma Day. It is celebrated by all Romany communites throughout the world, with parades of traditional costumes, dances, music and meetings. In 2007, there were few articles in the press about International Roma Day ${ }^{80}$. In 2008, after the tumultuous debates, radical opinions and wide media exposure of the Romany

ethnics living in nomadic camps in Emilia Romagna, Lazio, Calabria and Milano regions. The measure, although considered by the opposition as fascist and condemned by the Vatican, the European Union and NGOs, seemed to meet with the approval of the Romanian president. As explained by the police forces, the measure was seen as a preventive one (!): if a crime with an unknown author would be committed, the innocent would not be suspected. During three months more than 600 people were fingerprinted (children included) and while Romanian representatives tried to see the files and wanted to know what would happen with the data base, they received no answer from the Italian authorities.

${ }^{79}$ Adevărul (6), Evenimentul zilei (8), România liberă (2).

${ }^{80}$ Evenimentul zilei (1), România liberă (1). 
minority, their International Day received more attention in the Romanian press. ${ }^{81}$

\subsection{Romany Festivals}

Romany festivals are mainly organised and enjoyed by the "gadjii" (the white, non Roma) and they are a living proof of how culture unites. A lot of Romany artists participate in these festivals and their main motivation, as Florin Niculescu - the most well-known Romany violinist in Europe - says, they find this movement extraordinary, animated by a fabulous western spirit ${ }^{82}$. The festivals include music, dances, photo exhibitions and films, but also traditional craftsmen who show their creations in metal, wood and other materials. ${ }^{83}$

Of course, the classification is not exhaustive and concentrates on the main subjects that attracted the attention of the media during the last year. It is a subjective classification which is open to debate.

\section{Instead of a Conclusion, Two Images}

1 June 2008 - local elections in Romania. The opposition tried to gain control within the country, while the two parties that, four years previously, had made a coalition and won the election, were at merciless war. Between $8 \mathrm{pm}$ and $10 \mathrm{pm}$, the TV station that had the biggest audience was Acasă TV, which aired the last episode of a Romanian soap, "Inimă de țigan" [Gypsy heart]. The happy ending was watched in the urban milieu by 1,422,000 people, while the TV stations that presented the preliminary results of the local elections were watched by 493,000 (Pro TV), 472,000 (Antena 1), 318,000 (Antena 3) and 312,000 (Realitatea TV) viewers. ${ }^{84}$

A few years ago, Romania discovered a new rhythm in the form of 'manele' music, in which popular culture is associated with gypsy music. The singers of 'manele' are the most famous and appreciated artists in the country. Names like Adrian Copilu' Minune [Adrian the Wonder Kid], Florin Salam [Florin Salami], Vali Vijelie [Vali the Storm] made the Romany minority visible.

Invisible politically, Romany culture impregnated the everyday life of ordinary Romanians. And what if, in a world that is moving from the national to the global,

\footnotetext{
81 Adevărul (3), Evenimentul zilei (4), România liberă (3).

82 "Artist cu parfum de vedetă" [A star artist], Evenimentul zilei, nr. 4923, 12 September 2007, http:/ / www.evz.ro/articole/detalii-articol/459752/Artist-cu-parfum-de-vedeta/ [05/05/2008].

${ }^{83}$ Adevărul (2), Evenimentul zilei (10), România liberă (6).

${ }^{84}$ Scâteie Floriana, "Serialul Inimă de țigan a bătut alegerile locale" [Gypsy heart soap beat the local elections], Evenimentul zilei, nr. 5188, 3 June 2008, http:/ / www.evz.ro/ articole/detaliiarticol/806193/Serialul-Inima-de-tigan-a-batut-alegerile-locale-/ [05/05/2008].
} 
where the extreme right movements seem to be only reactionary responses to a fast changing environment, the minority culture will radically change the mainstream ones? 